Jurnal Biologi dan Pembelajarannya, Vol 6 No 2, Oktober 2019. Pp: 7-11

e-ISSN: $2406-8659$

\title{
HUBUNGAN KETERAMPILAN BERPIKIR KRITIS DENGAN KEMAMPUAN AKADEMIK MAHASISWA
}

\author{
Nur Hayati, Nindha Ayu Berlianti, dan Andri Wahyu Wijayadi \\ Program Studi Pendidikan IPA, Fakultas Ilmu Pendidikan, Universitas Hasyim Asy'ari Tebuireng Jombang \\ Email: nurhay.ht@gmail.com
}

\begin{abstract}
Abstrak
Tujuan penelitian ini untuk mengetahui hubungan antara keterampilan berpikir kritis dengan kemampuan akademik mahasiswa. Penelitian ini merupakan penelitian survei yang dilaksanakan pada semester genap 2018/2019. Sampel penelitian yang diambil berjumlah 57 mahasiswa prodi pendidikan IPA, Fakultas IImu Pendidikan, Universitas Hasyim Asy'ari Tebuireng Jombang yang telah menempuh matakuliah biologi dasar. Adapun instrumen penelitian ini yaitu tes keterampilan berpikir kritis berupa soal uraian. Analisis data dilakukan secara deskriptif kuantitatif dengan analisis korelasi pearson. Hasil analisis data menunjukkan adanya hubungan yang signifikan antara keterampilan berpikir kritis dengan kemampuan akademik mahasiswa yang ditunjukkan dengan nilai signifikansi sebesar 0.000 atau $\leq 0,05$. Berdasarkan nilai koefisien determinasi diketahui bahwa 46,92\% keterampilan berpikir kritis turut menentukan kemampuan akademik.
\end{abstract}

Kata kunci_Keterampilan berpikir kritis, Kemampuan akademik, Matakuliah biologi dasar

\section{PENDAHULUAN}

Abad ke-21 ditandai oleh munculnya era revolusi industri 4.0, di mana terjadi perubahan yang cepat dan fundamental di segala bidang, tidak terkecuali bidang pendidikan. Untuk dapat menghadapi era revolusi industri 4.0, sistem pendidikan harus diarahkan bukan hanya sekedar transfer pengetahuan tetapi juga mampu membentuk sumber daya manusia yang berkualitas dan memiliki kompetensi yang dibutuhkan di abad ke-21. Peserta didik harus dibekali dengan keterampilan berpikir tingkat tinggi agar dapat memecahkan masalah dalam kehidupan. Salah satu keterampilan berpikir tingkat tinggi yang diperlukan untuk memecahkan masalah adalah keterampilan berpikir kritis.

Ennis (2013:1) mendefinisikan berpikir kritis sebagai berpikir rasional untuk menentukan apa yang dipercaya dan dilakukan [1]. Menurut Halpern (1998:450), berpikir kritis adalah penggunaan keterampilan atau strategi kognitif yang meningkatkan kemungkinan hasil yang diinginkan [2]. Vijayaratnam (2009:1) menjelaskan berpikir kritis dalam arti sederhana sebagai kemampuan berpikir untuk diri sendiri secara andal dan bertanggungjawab dalam membuat keputusan yang mempengaruhi kehidupan orang lain [3]. Berkaitan dengan itu, Mitrevski \& Zajkov (2012:13) menyampaikan bahwa berpikir kritis merupakan aktivitas mental yang kompleks dan membutuhkan keterampilan berpikir tingkat tinggi dalam mengatasi masalah, membuat keputusan dan menarik kesimpulan [4]. Lebih lanjut, Chukwuyenum (2013:18) memaparkan bahwa berpikir kritis juga dapat melibatkan penalaran logis dan kemampuan untuk memisahkan fakta dari opini, memeriksa informasi secara kritis disertai bukti sebelum menerima atau menolak ide dan pertanyaan terkait dengan masalah yang dihadapi [5].

Facione (2013:5-7) memaparkan inti dari berpikir kritis ialah interpretasi, analisis, evaluasi, inferensi, eksplanasi, dan regulasi diri [6]. Interpretasi berarti memahami makna dari berbagai situasi, keputusan, data, pengalaman, peristiwa, konvensi, prosedur, keyakinan, kriteria atau aturan. Interpretasi meliputi keterampilan kategorisasi, decoding, dan memperjelas makna. Analisis mencakup keterampilan memeriksa ide-ide, mendeteksi argumen, dan menganalisis argumen. Evaluasi berarti mengakses kredibilitas pernyataan atau representasi lain yang mendeskripsikan presepsi, pengalaman, situasi, keputusan, atau pendapat seseorang. Selanjutnya, inferensi berarti mengidentifikasi berbagai unsur yang digunakan untuk menarik kesimpulan, menyusun hipotesis, mempertimbangkan informasi yang relevan, dan untuk memutuskan konsekuensi data, prinsip, dan bukti. Eksplanasi adalah kemampuan menghadirkan hasil penalaran seseorang yang meyakinkan dan koheren. Komponen yang terakhir adalah regulasi diri, yang berarti kesadaran diri untuk memantau aktivitas kognitif diri sendiri, unsur-unsur yang digunakan dalam aktivitas tersebut, serta evaluasi terhadap keputusan yang diambil.

Pentingnya berpikir kritis dimiliki oleh peserta didik karena memberikan banyak manfaat. Abbasi \& Izadpanah (2018:102) menjelaskan bahwa berpikir kritis sebagai salah satu kebutuhan abad ke-21 dan salah satu tujuan sistem pendidikan dapat membantu siswa untuk menjadi sukses dalam pendidikan mereka dan mendapatkan skor yang lebih tinggi [7]. Dalam sumber yang sama dinyatakan bahwa siswa dengan 
kemampuan berpikir kritis yang tinggi tidak mudah menerima informasi begitu saja dari lingkungan, mereka akan berpikir tentang cara yang mereka gunakan dan mempelajari perspektif yang berbeda pada masalah dan di akhir masalah, mengambil keputusan paling baik dan menindaklanjutinya. Mereka mampu memperoleh pengetahuan sendiri, mengevaluasi berbagai solusi dan akhirnya memilih yang terbaik. Selain itu juga dengan menerapkan dan memperkuat berpikir kritis, memungkinkan siswa untuk meningkatkan kemajuan mereka dan mendapatkan skor yang lebih tinggi. Hal senada juga disampaikan Verawati, et al. (2010:74) bahwa berpikir kritis sangat penting dalam setiap tindakan dan keputusan karena dengan memiliki pemikiran kritis yang baik, seseorang akan mampu memecahkan masalah [8]. Jadi, ketika siswa menemukan berbagai permasalahan, mereka akan dituntut menggunakan kemampuan berpikirnya untuk memberikan solusi terhadap permasalahan tersebut, sehingga terbiasa menyelesaikan berbagai permasalahan yang ada dalam kehidupan sehari-hari.

Matakuliah biologi dasar merupakan matakuliah yang mengkaji tentang konsep dasar biologi. Pada prodi pendidikan IPA, Fakultas IImu Pendidikan, Universitas Hasyim Asy'ari Tebuireng (UNHASY) Jombang, matakuliah biologi dasar disajikan pada semester genap (semester kedua) dengan bobot 2 SKS. Sangat penting bagi mahasiswa semester awal untuk dapat menguasai konsep dasar biologi sebagai acuan untuk dapat memahami konsep biologi secara menyeluruh. Selain itu mahasiswa diharapkan memiliki pemikiran kritis terhadap konsep biologi sehingga mampu mengaplikasikan konsep yang diperoleh untuk mengatasi berbagai permasalahan dalam kehidupan sehari-hari berkaitan dengan biologi. Diduga dengan berpikir kritis, akan membantu mahasiswa memiliki pemahaman yang mendalam terhadap konsep sehingga pada akhirnya akan berpengaruh terhadap peningkatan kemampuan akademiknya.

Hasil penelitian Abbasi \& Izadpanah (2018:101) menunjukkan bahwa berpikir kritis memiliki korelasi yang signifikan dan positif dengan pencapaian akademik pada pelajaran bahasa Inggris [7]. Penelitian lain yang dilakukan Dehghani, et al. (2011:24-29) pada mahasiswa pascasarjana juga memperlihatkan adanya hubungan yang signifikan antara capaian akademik dengan keterampilan berpikir kritis [9]. Lebih lanjut, berdasarkan hasil penelitian Permana, et al. (2019:5) diketahui bahwa kemampuan akademik berkontribusi secara efektif terhadap keterampilan berpikir kritis mahasiswa [10]. Berbeda dengan hasil penelitian Kanbay (2017:8) terhadap mahasiswa keperawatan yang menunjukkan bahwa tidak ada hubungan antara keterampilan berpikir kritis dengan pencapaian akademik [11]. Hasil penelitian senada dilakukan oleh Shirazi \& Heidari (2019:1) dengan hasil tidak terdapat hubungan yang signifikan antara keterampilan berpikir kritis dengan prestasi akademik [12]. Berdasarkan pemaparan tersebut peneliti terdorong melakukan penelitian untuk mengetahui hubungan antara keterampilan berpikir kritis dengan kemampuan akademik mahasiswa prodi pendidikan IPA UNHASY.

\section{METODE PENELITIAN}

Jenis penelitian ini adalah penelitian survei dengan tujuan untuk mengetahui hubungan antara keterampilan berpikir kritis dengan kemampuan akademik mahasiswa. Sampel penelitian terdiri atas 57 orang mahasiswa prodi pendidikan IPA, Fakultas IImu Pendidikan UNHASY yang telah menempuh matakuliah biologi dasar. Penelitian ini dilaksanakan pada semester genap 2018/2019. Data dianalisis secara deskriptif kuantitatif dengan analisis korelasi pearson correlation melalui SPSS 21.0. Instrumen penelitian berupa tes keterampilan berpikir kritis berjumlah 6 soal uraian. Adapun jumlah soal dan topik sesuai saran dari validator, yaitu Prof. Dr. Siti Zubaidah, M.Pd selaku dosen biologi Universitas Negeri Malang. Topik soal meliputi: sistem pernapasan, pencemaran lingkungan, zat aditif, sistem imun, sistem gerak dan sistem indera. Tiap topik diwakili satu soal. Soal nomor 1 tentang sistem pernapasan yaitu kebiasaan merokok, soal nomor 2 berkaitan dengan pencemaran lingkungan yaitu pengolahan sampah, soal nomor 3 mengenai penggunaan zat aditif pada makanan, soal nomor 4 mengenai sistem imun yaitu pemberian vaksin pada bayi, soal nomor 5 terkait sistem gerak yaitu pengaruh posisi duduk terhadap bentuk tulang, dan soal nomor 6 berhubungan dengan sistem indera yaitu kebiasaan-kebiasaan yang mempengaruhi kesehatan mata. Instrumen soal disusun berdasarkan acuan soal pra penelitian keterampilan berpikir kritis Prof. Dr. Siti Zubaidah, M.Pd.

Keterampilan berpikir kritis ini diukur dengan mengacu pada rubrik penilaian yang diadaptasi Zubaidah, dkk. (2015:211) dari Illinois Critical Thinking Essay Test dan Guidelines for Scoring Illinois Critical Thinking Essay Test yang dikembangkan oleh Finken \& Ennis (1993:17). Deskriptor instrumen keterampilan berpikir kritis ini meliputi kebenaran konsep, keterkaitan antarkonsep, alasan yang mendukung maupun menolak, kejelasan dalam berargumen, alur berpikir, evaluasi bukti yang logis serta seimbang, dan penggunaan tata bahasa.

Selanjutnya data hasil tes keterampilan berpikir kritis dianalisis korelasi menggunakan pearson correlation melalui SPSS 21.0. Indikator capaian skor keterampilan berpikir kritis mahasiswa dalam penelitian ini menggunakan rentangan skor 0-5 yang ditunjukkan pada Tabel 1. 
Jurnal Biologi dan Pembelajarannya, Vol 6 No 2, Oktober 2019. Pp: 7-11

e-ISSN: $2406-8659$

Tabel 1. Rentangan Indikator Capaian Skor Keterampilan Berpikir Kritis

\begin{tabular}{cl}
\hline Rentangan Indikator & \multicolumn{1}{c}{ Kriteria Keterampilan Berpikir Kritis } \\
\hline $0-2$ & Belum nampak atau masih kurang berkembang \\
$3-5$ & Berkembang dengan baik
\end{tabular}

Sumber: Zubaidah, dkk. (2015:209) diadaptasi dari Finken \& Ennis (1993:17)

\section{HASIL DAN PEMBAHASAN}

Setelah didapatkan data hasil penelitian, kemudian dilakukan analisis data dengan diawali uji prasyarat berupa uji normalitas dan homogenitas untuk mengetahui data normal dan homogen atau tidak. Hasil uji normalitas ditunjukkan pada Tabel 2.

Tabel 2. Hasil Uji Normalitas Data Hubungan Keterampilan Berpikir Kritis dengan Kemampuan Akademik

\begin{tabular}{lccccccr}
\hline & \multicolumn{3}{c}{ Kolmogorov-Smirnov } & \multicolumn{3}{c}{ Shapiro-Wilk } \\
\cline { 2 - 8 } & Statistic & df & Sig. & Statistic & df & Sig. \\
\hline Kemampuan Akademik & .107 & 57 & .162 & .969 & 57 & .151 \\
Keterampilan Berpikir Kritis & .108 & 57 & .096 & .978 & 57 & .390 \\
\hline
\end{tabular}

Berdasarkan Tabel 2. diketahui bahwa nilai signifikansi sebesar 0,162 atau $\geq 0,05$, ini menunjukkan bahwa data hasil penelitian ini normal. Selanjutnya hasil uji homogenitas dipaparkan pada Tabel 3.

Tabel 3. Hasil Uji Homogenitas Data Hubungan Keterampilan Berpikir Kritis dengan Kemampuan Akademik

\begin{tabular}{lrrrrr} 
& Levene Statistic & df1 & & df2 & Sig. \\
\hline Kemampuan Akademik & 1.690 & 9 & 41 & .123 \\
Keterampilan Berpikir Kritis &. & 9 &. &. \\
\hline
\end{tabular}

Tabel 3. menunjukkan bahwa nilai signifikansi sebesar 0,123 atau $\geq 0,05$, ini berarti bahwa data hasil penelitian ini homogen. Lebih lanjut dilakukan uji korelasi untuk mengetahui hubungan keterampilan berpikir kritis dengan kemampuan akademik yang ditunjukkan dengan Tabel 4.

Tabel 4. Hasil Uji Korelasi Data Hubungan Keterampilan Berpikir Kritis dengan Kemampuan Akademik

\begin{tabular}{llrr}
\hline & & $\begin{array}{c}\text { Kemampuan } \\
\text { Akademik }\end{array}$ & $\begin{array}{c}\text { Keterampilan } \\
\text { Berpikir Kritis }\end{array}$ \\
\hline Kemampuan & Pearson Correlation & 1 & $.685^{* *}$ \\
Akademik & Sig. (1-tailed) & 57 & .000 \\
& $\mathrm{~N}$ & $.685^{* *}$ & 57 \\
\hline Keterampilan & Pearson Correlation & .000 & 1 \\
Berpikir Kritis & Sig. (1-tailed) & 57 & 57 \\
\hline
\end{tabular}

**. Correlation is significant at the 0.01 level (1-tailed).

Hasil analisis data pada Tabel 4 menunjukkan bahwa nilai signifikansi sebesar 0,000 atau $\leq 0,05$, sehingga dapat disimpulkan bahwa terdapat hubungan yang signifikan antara keterampilan berpikir kritis dengan kemampuan akademik mahasiswa. Untuk menentukan seberapa besar kontribusi keterampilan berpikir kritis terhadap kemampuan akademik dilakukan dengan menghitung koefisien determinasi $R=r^{2} \times 100 \%$ atau $(0,685)^{2} \times 100 \%$ sehingga didapatkan koefisien determinasi sebesar $46,92 \%$. Dengan demikian dikatakan bahwa sebesar $46,92 \%$ keterampilan berpikir kritis turut menentukan kemampuan akademik. Atau dalam pengertian lain disimpulkan bahwa sebesar 53,08\% kemampuan akademik ditentukan oleh faktor lain. Dalam penelitian ini, faktor lain yang dimaksud misalnya motivasi belajar mahasiswa, gaya belajar mahasiswa, latar belakang keluarga, sumber belajar yang dimiliki mahasiswa dan faktor ekonomi. Menurut Mushtaq \& Khan (2012:21) berdasarkan hasil penelitian yang dilakukan terhadap mahasiswa di perguruan tinggi swasta di Rawalpindi dan Islamabad, prestasi akademik dipengaruhi oleh komunikasi, fasilitas pembelajaran, bimbingan yang tepat serta tekanan keluarga [15]. Faktor lain yang mempengaruhi prestasi akademik menurut Mohamed, et al. (2018:73) meliputi teknik pembelajaran, aspek yang berkaitan dengan keluarga, ketersediaan sumber fisik dan kebiasaan 
belajar. Lebih lanjut, Olufemi, et al. (2018:43) menyampaikan faktor yang berpengaruh terhadap prestasi akademik berasal dari faktor siswa, latar belakang orangtua, faktor sekolah dan faktor guru [16].

Hasil penelitian ini didukung hasil penelitian Abbasi \& Izadpanah (2018:101) yang menggambarkan adanya hubungan yang signifikan dan positif antara keterampilan berpikir kritis dengan pencapaian akademik [7]. Dengan kata lain, pencapaian akademik mengalami peningkatan seiring dengan berpikir kritis yang meningkat. Hasil penelitian Dehghani, et al. (2011:24-29) pada mahasiswa pascasarjana juga memperlihatkan adanya hubungan yang signifikan antara akademik yang dicapai dengan keterampilan berpikir kritis. Berdasarkan penelitian sebelumnya oleh Permana, et al. (2019:5) diketahui bahwa kemampuan akademik memberikan kontribusi secara efektif terhadap keterampilan berpikir kritis mahasiswa. Lebih lanjut, hasil penelitian Husnah (2017:10) menggambarkan bahwa tingkat berpikir kritis siswa berhubungan signifikan dengan hasil belajar. Berpikir kritis siswa memberikan sumbangan sebesar $82,7 \%$ terhadap hasil belajar. Semakin tinggi tingkat berpikir kritis siswa maka semakin besar hasil belajar yang diraih.

Berkaitan dengan hasil penelitian ini, adapun hubungan antara keterampilan berpikir kritis dengan kemampuan akademik dinyatakan oleh Setiawati \& Corebima (2017:3521) bahwa siswa dengan kemampuan akademik tinggi cenderung mempunyai keterampilan berpikir kritis yang lebih tinggi dibandingkan siswa dengan kemampuan akademik rendah. Disampaikan pula oleh Karbalaei (2012:122) bahwa pemikiran kritis yang kuat yang mendorong pengetahuan, keterampilan, dan disposisi kritis siswa dapat meningkatkan keberhasilan akademik siswa. Lebih lanjut, Afshar, et al. $(2014: 282,293)$ melalui hasil penelitiannya pada mahasiswa jurusan bahasa Inggris menjelaskan bahwa mahasiswa dengan kemampuan akademik tinggi memiliki kemandirian dan kemampuan kognitif yang lebih baik dibandingkan mahasiswa dengan kemampuan akademik rendah, sehingga mahasiswa dengan kemampuan akademik tinggi akan lebih mudah mencapai tujuan pendidikannya. Senada dengan hal tersebut, Dzulkifli \& Alias (2012:223) memaparkan bahwa kontrol emosi yang dimiliki mahasiswa kemampuan akademik rendah tidak terlalu baik jika dibandingkan mahasiswa yang kemampuan akademiknya tinggi, sehingga kemampuan berpikirnya juga rendah.

Hasil penelitian ini menggambarkan adanya hubungan yang signifikan antara keterampilan berpikir kritis dengan kemampuan akademik. Seseorang yang memiliki kemampuan akademik tinggi cenderung memiliki kemampuan yang baik dalam menganalisa dan mengevaluasi kemampuan yang dimilikinya, sehingga akan terdorong dan termotivasi untuk menganalisa informasi yang diperoleh secara kritis, misalnya terhadap permasalahan tertentu. Dengan demikian dapat dikatakan bahwa seseorang dengan kemampuan akademik tinggi menunjukkan kinerja yang tinggi dalam memecahkan masalah. Sementara ketika seseorang menganalisa informasi secara kritis, dia akan menggunakan kemampuan berpikir kritisnya yang melibatkan aktivitas mental yang kompleks dan keterampilan berpikir tingkat tinggi dalam mengolah informasi, mempertimbangkan berbagai kemungkinan penyelesaian disertai bukti yang mendukung, membuat keputusan dan menarik kesimpulan untuk mengatasi permasalahan yang dihadapi. Sehingga jelas bahwa keterampilan berpikir kritis berkorelasi dengan kemampuan akademik.

\section{SIMPULAN}

Berdasarkan hasil penelitian disimpulkan bahwa terdapat hubungan yang signifikan antara keterampilan berpikir kritis dengan kemampuan akademik mahasiswa dengan nilai signifikansi 0,000 . Keterampilan berpikir kritis memberikan kontribusi sebesar $46,92 \%$ terhadap kemampuan akademik mahasiswa. Adapun saran yang diajukan adalah pembelajaran di kelas perlu diarahkan untuk memberdayakan keterampilan berpikir kitis karena berkontribusi dalam meningkatkan kemampuan akademik peserta didik.

\section{SARAN}

\section{UCAPAN TERIMA KASIH}

Ucapan terima kasih yang sedalam-dalamnya penulis tujukan kepada Direktorat Riset dan Pengabdian Masyarakat, Direktorat Jenderal Penguatan Riset dan Pengembangan Kementerian Riset, Teknologi dan Pendidikan Tinggi Republik Indonesia yang telah memberikan pendanaan tahun 2019 atas Penelitian Dosen Pemula ini sehingga penelitian ini dapat terselesaikan dengan baik dan menghasilkan luaran sesuai yang diharapkan.

\section{DAFTAR PUSTAKA}

[1] Ennis, R.H. 2013. Critical Thinking Across the Curriculum (CTAC). Paper, 1-16.

[2] Halpern, D.F. 1998. Teaching Critical Thinking for Transfer Across Domains. Dispositions, Skills, Structure Training, and Metacognitive Monitoring. American Psychologist, 53(4), 449-455. 
Jurnal Biologi dan Pembelajarannya, Vol 6 No 2, Oktober 2019. Pp: 7-11

e-ISSN: $2406-8659$

[3] Vijayaratnam, P. 2009. Cooperative Learning as a Means to Developing Students' Critical and Creative Thinking Skills. Proceedings The $2^{\text {nd }}$ International Conference of Teaching and Learning (ICTL 2009) INTI University College Malaysia, 1-14.

[4] Mitrevski, B. \& Zajkov, O. 2012. Physics Lab, Critical Thinking and Gender Differences. Macedonian Physics Teacher, 48, 13-18.

[5] Chukwuyenum, A.N. 2013. Impact of Critical Thinking on Performance in Mathematics among Senior Secondary School Students in Lagos State. IOSR Journal of Research \& Method in Education (IOSR-JRME), 3(5), 18-25.

[6] Facione, P.A. 2013. Critical Thinking: What It Is and Why It Counts. Paper, 1-28.

[7] Abbasi, A. \& Izadpanah, S. 2018. The Relationship between Critical Thinking, Its Subscales and Academic Achievement of English Language Course: The Predictability of Educational Success Based on Critical Thinking. Academy Journal of Educational Sciences, 2(2), 91-105.

[8] Verawati, Arifin, S.R., Idris, R., \& Hamid, N.A.A. 2010. Gender Analysis of MyCT (Malaysian Critical Thinking) Instrument. Procedia Social and Behavioral Sciences, 7(C), 70-76.

[9] Dehghani, M., Mirdoraghi, F., \& Pakmehr, H. 2011. The Role of Graduate Students Achievement Goals in Their Critical Thinking Disposition. Procedia Social and Behavioral Sciences, 15, 2426-2430.

[10] Permana, T.I., Hindun, I., Rofi'ah, N.L. \& Azizah, A.S.N. 2019. Critical Thinking Skills: The Academic Ability, Mastering Concepts, and Analytical Skill of Undergraduate Students. Jurnal Pendidikan Biologi Indonesia, $5(1), 1-8$.

[11] Kanbay, Y., Işik, E., Aslan, Ö., Tektaş, P., \& Kiliç, N. 2017. Critical Thinking Skill and Academic Achievement Development in Nursing Students: Four-year Longitudinal Study. American Journal of Educational Research and Reviews, 2 (12), 1-10.

[12] Shirazi, F. \& Heidari, S. 2019. The Relationship between Critical Thinking Skills and Learning Styles and Academic Achievement of Nursing Students. The Journal of Nursing Research, 27(4), 1-7.

[13] Zubaidah, S., Corebima, A., \& Mistianah. 2015. Asesmen Berpikir Kritis Terintegrasi Tes Essay. Prosiding Symposium on Biology Education. Edubiodiversity: Inspiring Education with Biodiversity di Universitas Ahmad Dahlan Yogyakarta, 200-213.

[14] Mushtaq, I. \& Khan, S.N. 2012. Factors Affecting Students' Academic. Global Journal of Management and Business Research, 12(9), 16-22.

[15] Olufemi, O.T., Adediran, A.A. \& Oyediran, W.O. 2018. Factors Affecting Students' Academic Performance in Colleges of Education in Southwest, Nigeria. British Journal of Education, 6(10), 43-56.

[16] Afshar, H.S., Rahimi, A., \& Rahimi, M. 2014. Instrumental Motivation, Critical Thinking, Autonomy and Academic Achievement of Iranian EFL learners. Issues in Educational Research, 24(3), 281-298.

[17] Dzulkifli, M.A., \& Alias, I.A. 2012. Students of Low Academic Achievement-Their Personality, Mental Abilities and Academic Performance: How Counsellor Can Help? International Journal of Humanities and Social Science, 2(23), 220-225.

[18] Finken, M., \& Ennis, R.H. 1993. Illinois Critical Thinking Essay Test. Department of Educational Policy Studies, College of Education, University of Illinois, 1-17.

[19] Husnah, M. 2017. Hubungan Tingkat Berpikir Kritis terhadap Hasil Belajar Fisika Siswa dengan Menerapkan Model Pembelajaran Problem Based Learning, Journal of Physics and Science Learning (PASCAL), 1(2), 1017.

[20] Karbalaei, A. 2012. Critical Thinking and Academic Achievement. Ikala, 17(2), 121-128.

[21] Mohamed, A.A., Dahie, A.M. \& Warsame, A.A. 2018. Factors Affecting Student Academic Performance: Case Study from University of Somalia in Mogadishu-Somalia. IOSR Journal of Humanities and Social Science (IOSR-JHSS), 23(3), 73-10.

[22] Setiawati, H. \& Corebima, A.D. 2017. Research Article Empowering Critical Thinking Skills Of The Students Having Different Academic Ability in Biology Learning of Senior High School through PQ4R-TPS Strategy. The International Journal of Social Sciences and Humanities Invention, 4(5), 3521-3526. 